\title{
Translation Ideology in Translating Narrative Text: A Case Study on EFL Students' Translations
}

\author{
Cindy Kusuma Pertiwi ${ }^{1 *}$, Yusuf Al-Arief ${ }^{2}$, Emma Rosana Febriyanti $^{3}$ \\ 1, 2,3 Universitas Lambung Mangkurat \\ *Corresponding author. email 1710117320010@mhs.ulm.ac.id
}

\begin{abstract}
Nowadays, translation has become one of the centers of human interaction. In the translation process, translators ask to translate words or sentences considering the elements and meanings of the source language (SL) to the target language (TL). In translation, there are two ideologies, namely Domestication and Foreignization, which can use as references in translation to convey appropriately. This research aims to find out students' ideology in translating narrative text entitled "Malin Kundang" by English Language Education students' batch 2018 of Lambung Mangkurat University. In this research, the researcher analyzed the ideology used by students using a quantitative approach. The data is taking from the translation of the narrative text of twenty students who were selected using a purposive sampling technique. The results show that Domestication used 173 times, the frequency is $86,5 \%$, whereas Foreignization used 27 times, the frequency is $13,5 \%$. After conducting interviews with students who have worked on translated texts, it is concluded that by using Domestication ideology in translation, readers will find it easier to understand the meaning of the text, whereas, by using the Foreignization ideology in translation, readers can learn the elements and cultural meanings contained in the source language.
\end{abstract}

Keywords: Translation, Translation ideology, Domestication, Foreignization, Narrative text.

\section{INTRODUCTION}

Language is a means of unifying the national language; it is used as a means of communication and interaction between humans. Without language, it will not be easy to understand expressions, thoughts, and what interlocutors want to convey. Language is a process or set of processors used to ensure there is an agreement between the sender and receiver for meaning and assigned to symbols and schemes to combining them used for each communication. Each country in the world has a different language but the English language connects them as it is an international language.

However, learning English for Indonesian people is not easy because English is a foreign language. It requires great effort for students to learn language elements such as grammar, vocabulary, spelling, or pronunciation. The English elements are different from the Indonesian language. Even though communicating in English becomes a crucial issue especially at the university level, the university students who are assumed to have advanced abilities in terms of using written language, they still have a low ability to write their ideas or translate some texts. Students have difficulty translating texts, especially vocabulary and phrases [1].

Translation does not just change one language to another. Moreover, translation should give correct information based on the text source. For this situation, unfamiliar writing impacts much toward Indonesian writing since they are firmly related logically. The translation works to redirect messages starting with one language then onto the following language. Translation is "A craft consisting of the attempt to replace written messages and or statements in one language by the same message and or statements in other languages" [2]. The main idea of translation is to duplicate as precisely as conceivable every elements of language from the source language to the target language. Simultaneously, all actual data contained in the first text should be in translation. The point is to repeat as precisely as conceivable every one of the syntactic and lexical elements of the first 'source language' by discovering reciprocals in the 'target language.' Simultaneously, all 
actual data contained in the first text should be in translation.

Translation is not only linguistic transfer but also a social-historical phenomenon in which different ideologies and conflicts encounter with each other and a translation is thus the result of their reconciliation. Ideology is highly influential in both translators' decision-making process and reception of the target texts. Therefore, it is eminently reasonable to embed the theory of ideology into Translation Studies [3]. Cultural phenomena that commonly arise in translations are related to cultural differences between the two languages involved. The translator's ideology can determine his/her strategy to face the cultural problems. The decision introduces explicitly as ideology. A translator faces two decisions: whatever the person situates to the target readers, or recoveries the text, with all viewpoints in it. There are two negating propensities called domestication and foreignization.

The relation between translation and ideology has received increasing attention since the cultural turn in translation studies which sparked an interest in the historical aspect of translation [18].

Domestication and foreignization are two essential translations that provide linguistic and cultural guidance. Domestication is a type of translation that minimizes foreign elements of acidic texts with cultural values of target [4]. The culture of both languages is essential in the translation process, emphasizing translation from one language to another. Before translating a text, a translator must consider which culture is in the text and the extent to which language exists in that culture. A good translator must adjust the source and speakers of the objective language's culture, customs, and social game plans. Close to that, they should be acquainted with the two dialects' various talking styles and accepted practices. This mindfulness can work on the nature of translations to an incredible degree.

In translating, social content text may be a more critical variable than its genre. The rules for translating occur in a socio-cultural context. Consequently, it is essential to assess translation activities only in social contexts. Different cultures can have an impact on the concept of the world. These differences affect the language used as well. Thus, the exchange of two languages that occurred in translation is automatically related to exchanging two different cultures. Some people said that foreignization might be better than Domestication because it is more appropriate.

From the explanation above, this research problem is what is the ideology in translating narrative text entitled "Malin Kundang" by English Language Education
Study Program students' batch 2018 of Lambung Mangkurat University and the objective of this research is to find out students' ideology in translating narrative text entitled "Malin Kundang." The researcher used Malin Kundang's story because, in this story, there are many local terms. Therefore, it will be appropriate to the research question. The result of this research expects to provide helpful information both theoretically and practically. Theoretically, the findings of this research can enrich the theory in the field of translation studies, especially translation ideology, to expose what ideologies students used in translating narrative text and why they used it. Practically, the result of this research can provide input and feedback for students, lecturers, and other researchers.

\section{LITERATURE REVIEW}

\subsection{Translation}

Translation, in general, is the converting a text from a language to another without affecting the content or concepts included in the original text. Translation as "the rendering of a book's meaning into another language in the manner in which the author intended the text." Then translation allows science and technological innovation to flourish. However, because of the cultural differences, the translator must have the significant ability in the translating process. It has to do with the meaning of a language unit, which varies from country to country. In addition, Translation happens when someone contributes the meaning of the target language into a text so that the meaning comprehend by the readers and has an equal level with the author's intention for the text [4]. He added that translation entailed not just translating the language but also transferring the meaning of the text; therefore, the reader could understand the author's aim.

It is argued that translation is comprehensive (including contexts and texts), open (including subjective and objective uncertainties). Dynamic (changing with varied contexts and the target receptors' purposes) and human-brain-involved (including the minds of the translator and the interlocutors) [19]. Translation theory has traditionally focused mainly on the comparison of the source and the target texts, taking 'fidelity' as the basic criterion. However, above the criterion of fidelity, ideology has functioned as an 'invisible hand' in translation practice [20].

\subsection{Translation Ideology}

It is to argue that ideology in translation is not only based on the perspective of critical discourse analysis but also based on the perspective of cultural studies. Research on translation and ideology has two different 
perspectives that must be determined in advance, including ideological translation focuses on how the 'ideology' of a text to be translated is confronted with and how best to convey it into a translation. From this perspective, various discursive forms in a text are focused. Some of the obstacles that tend to relate to this are the use of language in social life, including values, belief systems that have been known by a group of individuals in certain social groups. For example, regime and feminism. Therefore, tends to express culture in SL into TL. The translation ideology becomes a term that includes something that is most basic not only in the text or its translation, but also what is contained in the text and its translation [5].

Ideology is an assumption, a belief, and a value system own by a specific community or a social group collectively. In line with the translation ideology is a dominant tendency of the community of the readers to the "right" or "wrong" in translation. It is the dominant tendency or taste of the readers of the "right," "accepted," and "good" translation. There are two translation ideology namely Domestication and Foreignization [8].

\subsubsection{Domestication}

Domestication is a translation ideology that has an orientation to the target language. The "right," "accepted," and "good" translation is the translation that fulfills the taste of the readers who expect the translated text to be suitable with the readers' culture (or taste) of the target language. The translated text should not taste like translated text and should taste as part of the writing tradition in the target language as possible.

Domestication is a method to ensure that the TL reader can read with ease. In addition, domestication is the transfer of cultural values from SL to TL to reduce the foreignness [4].

Domesticating approach is an ethnocentric reduction of a foreign text to target language cultural values, bringing the author back home, according to involve the essential tasks of selecting the foreign material to be translated and developing a way to translate it." o allude to translation strategies, he uses the terms domesticating and foreignizing [7][8]. As a result, domestication indicates that the translator's goal is to give the readers of the Target Text (TT) the impression that it writes in the Target Language from the start (TL). Domestication necessitates a translation that is as near to the target or reader's language as possible. Domestication translations appear to write in the native language. Domestication also refers to the target social-cultureoriented translation process, in which unique idioms from the target culture are utilized and transformed into more recognizable expressions.

A good translation should place the readers' needs as its focus. It means, the ideology of domestication is necessary to be used. Therefore, a translator should give priority of the audience over the forms of the language [13][21].

\subsubsection{Foreignization}

Foreignization ideology has the orientation to the source language. The "right," accepted," and "good" translation is the translation that fulfills the taste of the readers and publisher who expect the existence of the translated text to be suitable with the target language culture (or taste) or who consider the existence of foreign culture is beneficial for the society. Foreignization is a method to ensure that the Target Language reader gets the sense of Source Language culture through reading the translation product [4].

Foreignization is a source-culture-oriented translation that aims to preserve as much foreign flavor as possible while transferring the source language and culture to the target language [9]

\subsection{Source Language}

Source language describe as the language in which the original author of a message formulated it, and the point of departure for translation [10]. The language to be translated is the source language (SL) [11]. The source language is defined as a language that is translated into another language. Furthermore, the source language is the language utilized as a medium of instruction in teaching foreign languages; on the other hand, the source language is the language from which loanwords are derived [12].

\subsection{Target Language}

The receptor language, also known as the target language, is the language into which a message is translated from the original or source language [13]. The target language is the language that will be translated into or arrived at (TL) [11]. The target language is the language that becomes the medium of a message that comes from the source language after going through the transfer process. On the other hand, the target language also means the language used to describe the meaning of the entry contained in the dictionary [14].

\subsection{Narrative Text}

Narrative text describes a series of events that occurred to a person or a character. A person, animal, 
plant, or thing can be the protagonist. The narrative mode, or the set of strategies used to tell the narrative through a process narration, is an essential aspect of narrative text. Narrative is a type of discourse that attempts to narrate events so that the readers may see or experience them [15]. As a result, the aspect of the act or acts is the most significant element in a narrative. Narratives often deal with socially harmful events or situations that require a remedy other than pleasure. The narrative text is one type of text used to entertain events or problems that led to a crisis that eventually found a solution.

\section{METHOD}

This study adopted a descriptive quantitative approach because the data was in the form of numbers which was then described and elaborated to provide a detailed description of the number of ideologies used by by the English Language Education Study Program students batch 2018 of Lambung Mangkurat University in translating a narrative text entitled "Malin Kundang" from Indonesian to English and their reasons of using.

The research involved twenty students of English Language Education Study Program in Lambung Mangkurat University as the research sample. The data collection was carried out by using tests and interviews. First, students were asked to translate narrative text entitled "Malin Kundang," after that, they were asked some questions about their strategies in translation which was helpful for strengthening the result of the research.

The data was obtained from students' translation results which were analyzed by using the classification rubric as seen in table 1 and counted by using the formula as seen below:

\begin{tabular}{|l|}
\hline Terms of content Domestication Foreignization \\
\hline SL : \\
Perkampungan \\
Pantai Air Manis \\
TL : .... \\
\hline SL : Mande \\
Rubayah \\
TL : .... \\
\hline SL : Tabib \\
TL : ..... \\
\hline SL : Merantau \\
TL : .... \\
\hline
\end{tabular}

\begin{tabular}{|c|}
\hline $\begin{array}{l}\text { SL : Nasi } \\
\text { berbungkus } \\
\text { daun pisang } \\
\text { TL : ..... }\end{array}$ \\
\hline $\begin{array}{l}\text { SL : Tetua Desa } \\
\text { TL : .... }\end{array}$ \\
\hline $\begin{array}{l}\text { SL : Cuih! } \\
\text { TL : .... }\end{array}$ \\
\hline $\begin{array}{l}\text { SL : Dekil } \\
\text { TL : .... }\end{array}$ \\
\hline $\begin{array}{l}\text { SL : Allah Yang } \\
\text { Maha Kuasa } \\
\text { TL : .... }\end{array}$ \\
\hline $\begin{array}{l}\text { SL : Kutuk } \\
\text { TL : ..... }\end{array}$ \\
\hline $\begin{array}{l}\mathbf{X}=\sum_{\mathbf{N}} \times 100 \% \\
\mathbf{Y}=\underset{\mathbf{N}}{\sum_{\mathrm{N}}} \times 100 \%\end{array}$ \\
\hline
\end{tabular}

\section{Explanation:}

$X$ : Students using Domestication ideology

Y : Students using Foreignization ideology

$\mathrm{N}$ : The total number of the data

$\sum:$ The frequency of students use

\section{RESULT AND DISCUSSION}

The data was taken from a narrative text entitled "Malin Kundang." The data consisted of ten cultural terms as the source of the data. There were twenty students who were asked to translate narrative text. The data analysis showed that there were two translation ideologies found in the data. It means that all the translation ideologies were used by the students in translating narrative text. The total number of the data can be seen in table 2:

Table 2 Classification of Translation Ideology

\begin{tabular}{|lcc|}
\hline No. & Ideology & Frequency \\
\hline 1. & Domestication & 173 \\
\hline 2. & Foreignization & 27 \\
\hline Total & & 200 \\
\hline
\end{tabular}

In the translation process, students were asked to examine the source of the language. They have to consider many things when translating the text into the 
target language because of the differences in cultural elements between the source language and the target language. In translating words or sentences containing cultural elements, they must translate them by finding equivalent words in the target language or retaining the source language when translating the text. For example, the Indonesian language and English, both languages, have different cultural elements that will affect the language used in the translation. From these differences, an ideology is needed that can be used as a reference in translation.

Since this research is about the translation ideology in translating narrative text, the students were asked to choose an ideology that will be used as a reference when translating narrative texts. Based on the result, translation ideology used by the research subjects in translating narrative text entitled "Malin Kundang" from the Indonesian language into English was all of the translation ideologies. Domestication is the transfer of cultural values from the source language (SL) to the target language (TL) to reduce foreignness. On the other hand, foreignization is a method of making the source language (SL) cultural values more prominent and visible to the target language (TL) [4]

From the results of the test and interview, it was found that $86.5 \%$ of students chose to use the domestication ideology in translating a text. For example, translating the word "tabib," using the domestication ideology oriented to the target language, the subjects translated the word into "healer, physician, and shaman." The reason for that was to help the readers to understand the meaning of the translated text. In line with that, for adherents of the domesticating ideology, words such as Mr, Mrs, Uncle, Aunt, and so on must be translated into Indonesian so that the entire translation is present as part of the Indonesian language so that readers can accept it [16].

Meanwhile, it was found that $13.5 \%$ of students chose to use foreignization ideology in translating the text. For example, in the phrase "Mande Rubayah" which used a foreignization ideology oriented towards the source language, the subjects of the study did not translate the phrase into English. Instead, they used the original pharse as "Mande Rubayah" so that the readers could learn the elements and cultural meaning contained in the source language. Similarly, if a translator who adheres to the ideology of foreignization does not translate the words Mr, Mrs, Mom, Dad, or some other foreign words into target language, the reasons are because such words are familiar to Indonesian readers and that readers can acquire knowledge of other cultures by learning from some foreign words that are not translated [16].
From the findings, it was found that more students used the ideology of domestication than the ideology of foreignization in translating narrative texts. This finding is consistent with the theory that in order to overcome the problem of translating cultural words, the translator tends to reduce the foreignness in the target language text, allowing readers of the target language text to understand the unfamiliar cultural words from the source-language text [17].

\section{CONCLUSION}

From twenty words and phrases containing cultural terms in the narrative text entitled "Malin Kundang," it was found that English Language Education Study Program students' at Lambung Mangkurat University used all the ideologies proposed by Venuti [8]. The result is that students mostly use domestication ideology, which is 173 times with a percentage of $86.6 \%$, whereas foreignization ideology is used 27 times with a percentage of $13.5 \%$.

Based on the results of interviews and discussions, students mostly use the domestication ideology because by using the domestication ideology in translation the readers will find it easier to understand the meaning of the translated text. In contrast, by using foreignization ideology, the readers can learn the elements and cultural meaning contained in the source language.

Referring to the findings, it is suggested that EFL students are exposed to more practices on using translation strategy and to choose wisely the translation ideology they want to use in translating the text. Therefore, the translation results can be well received and easy to understand to the readers.

\section{AUTHORS' CONTRIBUTIONS}

Author 1 contributed to the reviewing of literature, designing research instruments, collecting the data, and analyzing the data. Author 2 contributed to the design of the research, data analysis, and writing the report. Finally, Author 3 contributed to literature review and writing format.

\section{ACKNOWLEDGMENTS}

The authors are thankful to the subjects of the research who were willing to participate in this research. 


\section{REFERENCES}

[1] A. Susanty, Studi Kesulitan Penerjemahan Bahasa Inggris-Indonesia Mahasiswa Jurusan PLS FKIP Universitas Bandung Raya, 2019.

[2] P. Newmark, A Textbook of Transaltion, New York and London, PrenticeHall, 1998.

[3] Y. Fang, Ideology of Translation vs Translation of Ideology: A Study on the Nation of Ideology in Translation Studies, Sichuan University, China Academic Journal Electronic Publishing House, 2011.

[4] J. Munday, Introducing Translation Studies, New York, Routledge, 2001.

[5] A. Ryan, The Ideology of Translation VS Translation Procedures, Regular Issue Article, New York, 2020

[6] B. Hatim, M. Jeremy Munday, Translation, An Advanced Residence Book, New York, Routhledge. 2004.

[7] L. Venuti, The Translator's Invisibility: A History of Translation, New York, Routledge, 1995.

[8] L. Venuti, Strategies of Translation. In M. Baker (Ed.), Encyclopedia of Translation Studies, London and New York, Routledge, 1998.

[9] M. Shuttleworth, M. Cowie, Dictionary of Translation Studies, Manchester, Manchester University Press. JP3M, vol. 1, 1997, pp. 1-8.

[10] N. Nida, A. Eugene, R. Charles, T. Taber, The Theory and Practice of Translation Leiden, Netherlands, The United Bible Societies, 1974.

[11] M. Foster, Translation from/in Farsi and English, Retrieved April, 2021, from http://www.parasa.ts.com/index.htm. 1958.

[12] Lektur.ID. 2 Arti Bahasa Sasaran di Kamus Besar Bahasa Indonesia (KBBI). Accessed on May, $2^{\text {nd }}$ 2021, from https://lektur.id/arti-bahasa-sasaran/

[13] E. A. Nida, R.T. Charles, The Theory and Practice of Translation, Leiden, The Netherlands, E.J. Brill, 1982.

[14] Lektur.ID. 3 Arti Bahasa Sasaran di Kamus Besar Bahasa Indonesia (KBBI). Accessed on Mey, $2^{\text {nd }}$ 2021, from https://lektur.id/arti-bahasa-sumber/

[15] L. Keraf, M. Mildred, Meaning-Based Translation. Diksi dan Gaya Bahasa, Jakarta, Gramedia Pustaka Utama, 1984.

[16] R. Amalia, Translation Ideology of Cultural Word in Nanny Diaries Novel into Buku Harian Nanny. Sarjana's Thesis, State Islamic University Syarif Hidayatullah Jakarta, 2014.
[17] R. Faizzah, Foreignization and Domestication of Indonesian Cultural Words in the English Translation of Pramoedya Ananta Toer's Jejak Langkah, Sarjana Thesis, State Islamic University Sunan Kalijaga Yogyakarta, 2018.

[18] N. B. Aksoy, The Relation between Translation and Ideology as an Instrument for the Establishment of a National Literature, Meta. 2010.

[19] L. Dai, Ideology in Translation: Theories and Reflections, Wuhan, China, Atlantis Press, 2016.

[20] L. S. Grant, Ideology of Translation Concept Approach on Determining a Decision by the Translator, Linguistics and Culture Review, 2017.

[21] H. Hidayati, N. Niswatin, Analysis of Translation Technique, Methods, and Ideology on Children's Billingual Story Books. Alsuna, in: Proceedings of Journal of Arabic and English Language. 2020 